\title{
Botanical extracts against the potato tuber moth, Phthorimaea operculella (Zeller 1873) (Lepidoptera: Gelechiidae), during storage conditions
}

\author{
Aziza Mohamed Fouad Sharaby', Mohamed Ahmed Gesraha ${ }^{1 *}$ (D) and Sahar Ahmed Baker Fallatah²
}

\begin{abstract}
The potato tuber moth (PTM), Phthorimaea operculella (Zeller 1873) (Lepidoptera: Gelechiidae), is a destructive pest of stored potatoes and potato crop. Biopesticides are certain types of pesticides derived from animals, plants, and bacteria. Botanicals are especially efficient in the form of antifeedant, repellent, protectants, and growth-disrupting hormones. They are also sources of secondary metabolites that are safer than synthetic insecticides. Present research was conducted to evaluate some botanical extracts as natural local alternatives against PTM under storage conditions. Twelve different $80 \%$ ethanolic plant extracts were tested on PTM during storage condition $\left(30 \pm 2^{\circ} \mathrm{C}\right.$ and $70 \pm 5 \% \mathrm{RH}$ ) at a light regime of the day 10-h light and 14-h dark. Biological parameters of the pest, evidence of the potato tubers damage, and continuation of protection to the tubers were recorded. Extracts of mint, zygophyllum, coriander, arnoglosse, harmel, and solanum indicated a total inhibition of egg deposition at $2.5 \%$ concentration; also, they provided high protections to the potato tubers from the PTM infestation for about 3 months and without observations' effect on tubers germination. Senna, colocynth, and basil reduced the number of deposited egg/female. Jasmine, geranium, and chamomile recorded a low potential on egg deposition. Basil showed the highest potency in decreasing development of larvae that hatched from eggs, therefore, reduced the number of next adult offspring $\left(F_{1}\right)$ and followed by jasmine and geranium. Variable levels of extracts' protection can be arranged according to their damage evidence as follows: basil > colocynth > jasmine > geranium > senna $>$ chamomile.
\end{abstract}

Keywords: Phthorimaea operculella, Botanical extracts, Storage conditions, Potential

\section{Background}

The potato tuber moth (PTM), Phthorimaea operculella (Zeller 1873) (Lepidoptera: Gelechiidae), is an oligophagous insect species found worldwide attacking solanasis family, causing great losses in potatoes' quantity and quality. It is a very economical pest of potato crop during storage and marketing (Rondon, 2010). Moths infest tubers during storage at harvesting and/or through

\footnotetext{
*Correspondence: mgesraha@gmail.com

'Pests \& Plant Protection Dept. Agricultural \& Biological Researches Division, National Research Centre, Cairo, Egypt

Full list of author information is available at the end of the article
}

entering the store outlets. Tubers become unsuitable for sale or consumption after infestation, then its damages increases gradually after several insect generations during the storage period. Application of chemical pesticides led to a contamination and pollution of environment, causing intoxication of non-target beneficial insects and development of pesticide resistance among target insects (Mathew, 2016). The plant kingdom is a source of secondary metabolites or phytochemicals for self defense, some of them have biopesticide potentials (Isman, 2008), such as phenols, flavonoids, terpenoids, quinines, tannins, alkaloids, saponins, 
coumarins, and sterols, which have significant variations in their impact effects against many insect pest species (Mathew, 2016). Many studies have shown that wild medicinal and ornamental plants have pesticides properties showing antifeedant, repellent, growth regulators effects, and/or toxic activities on a wide range of insect pests (Sharaby, 1988; Onu et al. 2015 and Chandel et al. 2018).

Present studies aimed to evaluate the potentials of usage of 12 plant extracts as biopesticides against the PTM, providing a protection to stored tubers in the stores and through marketing, and evaluate the period of their continuation for injury prevention.

\section{Materials and methods}

\section{Phthorimaea operculella stock culture}

A stock colony of PTM was initiated on potato tubers, Solanum tuberosum L. Infested potato tubers were maintained in rearing wooden cages, described by ElSherif (1966), in a storage room at $30 \pm 2{ }^{\circ} \mathrm{C}$ and $70 \pm$ $5 \% \mathrm{RH}$, at a light regime of the day 10-h light and 14-h dark. After pupation, the cocoons were collected and the moths emerged were used in different experiments. New clean tubers were introduced every 20 days in order to maintain the insect culture.

\section{Plant extracts}

Twelve different plants (zygophyllum, solanum, coriander, arnoglosse, jasmine, senna, colocynth, chamomile, harmel, geranium, basil, and mint), locally available in field of the Eastern Province of Saudi Arabian Kingdom, were air-dried under a shade for 2 weeks (Table 1). The air-dried materials were grinded into fine powders and kept in tight containers until use. Different prepared plant powders were extracted by ethanol $80 \%$ and soaked as mentioned by Freedman et al. (1979). Each crude extract was mixed at
$2.5 \%$ with talcum powder (magnesium silicate) as inert carrier substrate. Potato tubers were shacked well with $25 \mathrm{~g}$ of the extract treated with talcum powder $/ 1 \mathrm{~kg}$ tubers until tubers were completely covered and the treated powders stacked well to the tuber peel. The experiments were distributed in a randomized complete block design. Different biological parameters of the treatments were calculated and damage evidence to tubers and continuation of injury prevention during different intervals of storage were recorded.

\section{Effects of the plant extracts on some biological parameters of the PTM}

Treated tubers were distributed into 5 glass jars $(2 \mathrm{~L}$ capacity); 6 newly emerged moths were collected from the stock culture $\left(3 q+3{ }^{\lambda}\right)$, introduced inside each jar, and covered with a piece of a black organza cloth. Each experiment was arranged completely randomized at storage room. Eggs laid on the treated tubers were collected daily for 10 days. Infested tubers were collected daily also till the end of egg deposition. Total number of the deposited eggs/treatment was calculated. The infested tubers at each treatment were left to complete larval development, pupation, and emergence of new moths $\left(F_{1}\right)$. For the control, two tests were run, the first tubers were left without treatments, and the second, the tubers were treated by talcum powder only. Biological parameters were the number of deposited egg/treatment, $\%$ of emerged moths $\left(\mathrm{F}_{1}\right)$, and developmental period (egg to adult).

\section{Evidence of tuber damage}

Tuber damage index (DI) were estimated and illustrated in Fig. 2, showing the different strength of plant extracts applied in protection. Assessment of the mean index of

Table 1 List of the tested plant extracts

\begin{tabular}{|c|c|c|c|}
\hline Scientific name & English name & Family & Plant part used \\
\hline Zygophyllum coccineum $\mathrm{L}$. & Zygophyllum & Zygophyllaceae & Leaves \\
\hline Solanum villosum Miller & Solanum & Solanaceae & Leaves \\
\hline Coriandrum sativum L. & Coriander & Umbelliferea & Leaves \\
\hline Plantago albicans L. & Arnoglosse & Plantaginaceae & Leaves \\
\hline Jasminum grandiflorum L. & Jasmine & Oleaceae & Leaves and flowers \\
\hline Cassia senna $\mathrm{L}$. & Senna & Liguminosae & Leaves \\
\hline Citrullus cucumis L. & Colocynth & Cucurbitaceae & Fruit \\
\hline Anthemis deserti Boiss. & Chamomile & Compositae & Whole plant \\
\hline Rhazya stricta Decne & Harmel & Apocynaceae & Leaves \\
\hline Pelargonium graveolens L. & Geranium & Geraniaceae & Leaves \\
\hline Ocimum basilicum L & Basil & Lamiaceae & Leaves and flowers \\
\hline Mentha viridis $\mathrm{L}$. & Mint & Lamiaceae & Leaves \\
\hline
\end{tabular}


tubers' damage was determined according the equation recorded by (Fenemore, 1980) as

$$
\mathrm{DI}=\frac{\text { No.Slight }\left(\mathrm{X}_{1}\right)+\text { No.Moderate }\left(\mathrm{X}_{2}\right)+\text { No.Severe }\left(\mathrm{X}_{3}\right)}{\text { Total number of tubers }} \times 10
$$

Where

Clean $(0)=$ no visible of sign infestation

Slight $\left(\mathrm{X}_{1}\right)=$ one or two mines, which could be removed readily in peeling

Moderate $\left(\mathrm{X}_{2}\right)=$ more than two mines present, and up to one-third of surface showing damage

Severe $\left(\mathrm{X}_{3}\right)=$ more than one-third of the tuber surface showing damage

All tests were replicated 10 times under the storage condition of the stock cultures.

\section{Protecting stored tubers from PTM infestation}

Ten kilograms of clean potato tubers were mixed and shacked well by $250 \mathrm{~g}$ of treated talcum powder that was previously mixed with the tested plant extracts $(25 \mathrm{gm}$ extract $/ 1 \mathrm{k}$ talcum powder). Each treatment was distributed into $102-\mathrm{L}$ jars that contained $1 \mathrm{~kg}$ treated tubers and 6 newly emerged moths, introduced to each replicate $(3 \hat{\jmath}+3$ ㅇ $)$. Percentages of damage index were recorded at different intervals of exposure time $(2,4,6,8$, 10 , and 12 weeks), post-egg deposition, and hatching.
Test of potato tubers germination

One kilogram of the new treated tubers from each tested plant extract was left for 2-3 weeks in the storage room, then the growth of buds or sprouts was observed and percent of tubers germination was calculated.

\section{Statistical analysis}

Mortality rate was corrected using Abbott's formula (Abbott, 1925). All data were statistically subjected to analysis of variance (ANOVA) through SPSS Computer program (IBM SPSS Statistics for Windows, Version 22.0. Armonk, NY: IBM Corp. released in 2015), and significantly different means were separated using least significant difference (LSD).

\section{Results and discussion Biological parameters}

Present investigation cleared significant effects $(P<0.01)$ of all the tested extracts on the mean number of deposited egg on the treated tubers laid by female moths exposed to the treated tubers. Six of the 12 tested extracts induced complete protections were mint, coriander, zygophylum, arnoglosse, harmel, and solanum (Fig. 1). They had oviposition deterrents, followed by the other extracts with different degrees of protection: senna, colocynth, and basil with a mean number of deposited eggs ranged from 3 to 5 eggs/tuber, compared to 26.2 and 31.6 for the 2 control tested (talcum powder and untreated tubers), respectively. Extracts of jasmine,

\section{Effect of Plant Extracts}

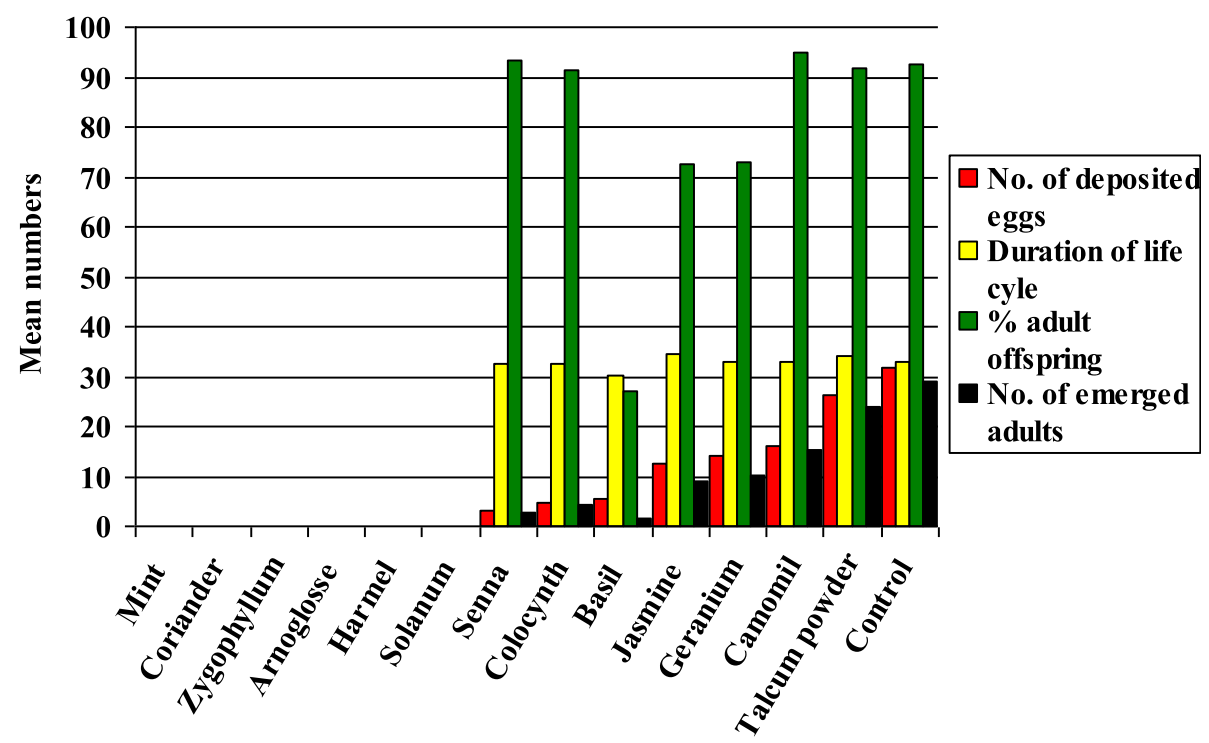

Tested Plant Extracts

Fig. 1 Effect of botanical extracts on some biological parameters of Phthorimaea operculella 
Table 2 Continuity of extracts in preventing the stored tubers from PTM infestation during different periods

\begin{tabular}{|c|c|c|c|c|c|c|}
\hline \multirow[t]{2}{*}{ Tested extracts } & 2 weeks & 4 weeks & 6 weeks & 8 weeks & 10 weeks & 12 weeks \\
\hline & \multicolumn{6}{|l|}{ Mean \pm SE } \\
\hline Mint & $O f$ & $O f$ & $O f$ & $1.80 \pm 0.68 \mathrm{fg}$ & $4.70 \pm 1.80 \mathrm{~g}$ & $5.33 \pm 1.60 \mathrm{~h}$ \\
\hline Coriander & $O f$ & $O f$ & $O f$ & $3.70 \pm 0.0 .29 f$ & $4.30 \pm 0.14 \mathrm{~g}$ & $4.45 \pm 0.18 h$ \\
\hline Zygophyllum & $O f$ & $0 f$ & of & $3.17 \pm 1.80 \mathrm{f}$ & $3.44 \pm 0.27 \mathrm{~g}$ & $4.11 \pm 0.46 h$ \\
\hline Arnoglosse & $4.67 \pm 0.33 \mathrm{e}$ & $6.33 \pm 0.67 e$ & $7.33 \pm 1.45 \mathrm{e}$ & $7.33 \pm 1.45 \mathrm{e}$ & $8.53 \pm 1.99 f$ & $9.66 \pm 1.60 f$ \\
\hline Harmel & $O f$ & $0 f$ & of & $3.97 \pm 0.70 f$ & $4.70 \pm 0.79 \mathrm{~g}$ & $5.52 \pm 0.60 h$ \\
\hline Solanum & $O f$ & $0 f$ & of & $0 \mathrm{~g}$ & $6.50 \pm 0.40 \mathrm{fg}$ & $6.70 \pm 0.32 \mathrm{gh}$ \\
\hline Basil & $5.93 \pm 0.37 \mathrm{e}$ & $6.73 \pm 0.27 \mathrm{e}$ & $6.73 \pm 0.27 \mathrm{e}$ & $8.17 \pm 0.99 \mathrm{e}$ & $8.93 \pm 0.68 f$ & $9.04 \pm 0.76 \mathrm{fg}$ \\
\hline Colocynth & $12.00 \pm 1.15 \mathrm{~d}$ & $13.00 \pm 1.53 \mathrm{~d}$ & $13.33 \pm 1.67 \mathrm{~d}$ & $13.33 \pm 1.67 \mathrm{~d}$ & $14.80 \pm 2.50 \mathrm{e}$ & $15.74 \pm 1.58 \mathrm{e}$ \\
\hline Jasmine & $17.67 \pm 0.33 c$ & $18.30 \pm 0.33 c$ & $18.66 \pm 0.33 c$ & $19.56 \pm 0.64 c$ & $19.70 \pm 0.61 d$ & $19.70 \pm 0.60 \mathrm{~d}$ \\
\hline Geranium & $18.67 \pm 0.33 c$ & $19.67 \pm 0.33 c$ & $20.00 \pm 0.00 c$ & $20.86 \pm 0.86 c$ & $21.78 \pm 0.89 \mathrm{~cd}$ & $22.44 \pm 0.22 c$ \\
\hline Senna & $22.33 \pm 0.88 b$ & $23.00 \pm 1.16 b$ & $23.67 \pm 0.67 b$ & $23.67 \pm 0.67 b$ & $24.03 \pm 0.49 b c$ & $24.03 \pm 0.48 b c$ \\
\hline Chamomile & $23.05 \pm 0.76 b$ & $24.17 \pm 1.01 b$ & $25.10 \pm 0.59 b$ & $25.10 \pm 0.59 b$ & $25.43 \pm 0.72 b$ & $25.53 \pm 0.62 b$ \\
\hline Talcum powder & $28.00 \pm 0.33 a$ & $28.36 \pm 0.33 a$ & $29.33 \pm 0.30 \mathrm{a}$ & $29.77 \pm 0.23 \mathrm{a}$ & $29.77 \pm 0.23 \mathrm{a}$ & $29.40 \pm 0.29 a$ \\
\hline Control & $30.00 \pm 0.00 a$ & $30.00 \pm 0.00 a$ & $30.00 \pm 0.00 a$ & $30.00 \pm 0.00 a$ & $30.00 \pm 0.00 \mathrm{a}$ & $30.00 \pm 0.00 a$ \\
\hline LSD $_{0.05}$ & 1.79 & 2.33 & 2.42 & 2.33 & 3.19 & 2.49 \\
\hline LSD 0.01 & 2.46 & 3.19 & 3.32 & 3.24 & 4.31 & 3.34 \\
\hline
\end{tabular}

The maximum possible index was thus 30 tunnels/tuber, if all tubers fall into the sever category according Fenemore (1980)

geranium, chamomile, and basil induced lower protections than the other previous mentioned extracts, where the number of deposited eggs ranged from 12.4 to 16.2 eggs/tuber. Basil decreased the developmental period (from egg-laying to moths of F1) and also played a role as a growth regulator. Basil extract reduced the deposited eggs and resulting moths and induced some toxicity for the developing larvae, produced low insect population, and protected the tubers from infestation to a great extent. Senna $>$ colocynth $>$ basil $>$ jasmine $>$ geranium, achieved great reductions in egg deposition with some effects on the larval development inside the infested tubers. They had some toxicity to the larval development. Chamomile had the least toxicity. All the 6 extracts caused tuber protection by variable means, as repulsions from a distance with a complete protection as mint, coriander, zygophylum, arnoglosse, harmel, and solanum. Other extracts showed growth retardants or

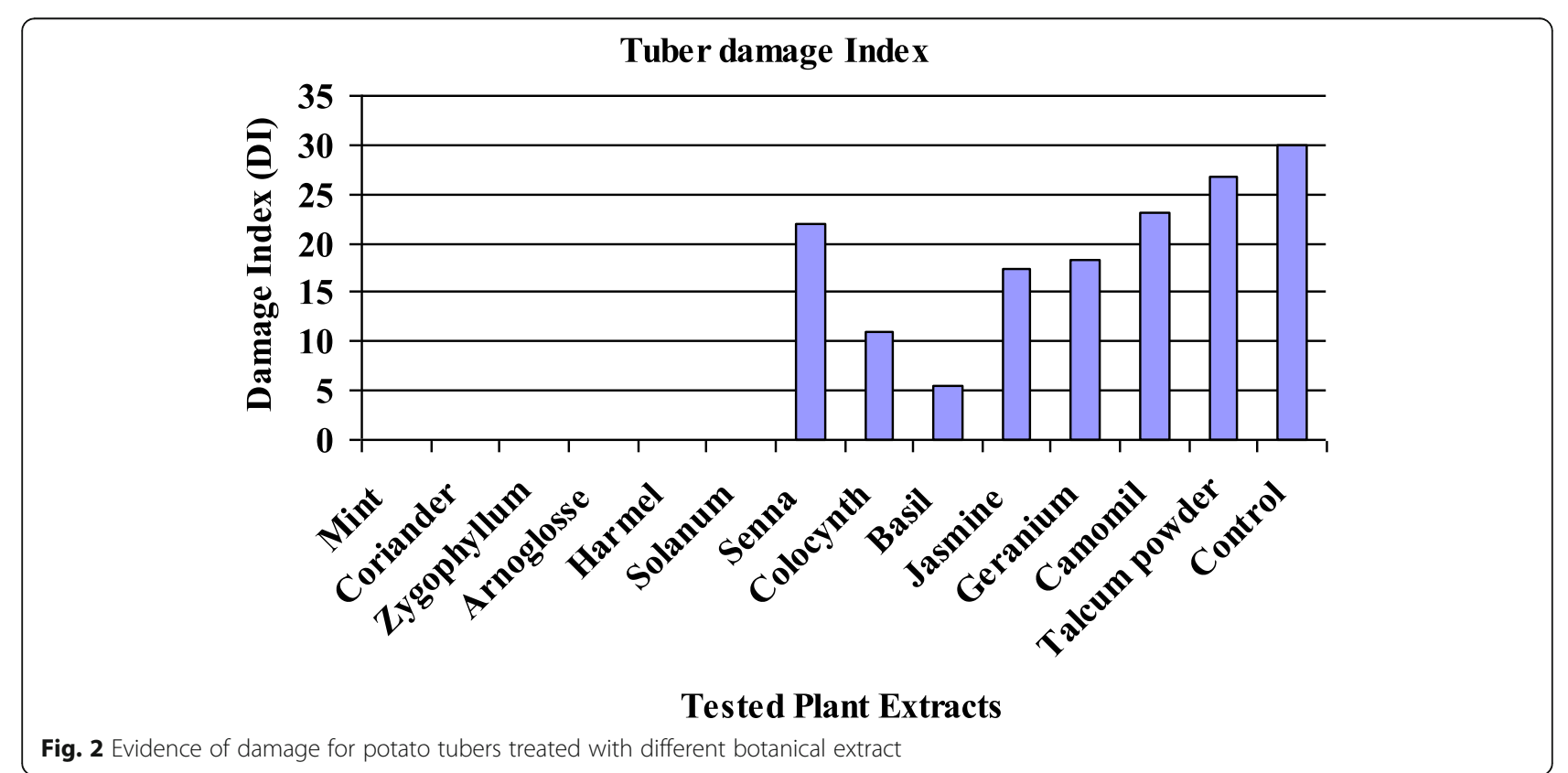


toxicants with variable degrees: senna $>$ colocynth $>$ basil $>$ jasmine $>$ geranium $>$ chamomile as indicated in Fig. 1.

\section{Protecting stored tubers from PTM infestation}

Protection for more than 3 months at significant level $P$ $<0.01$ was achieved (Table 2). All extract treatments had not affected tuber germination. Solanum gave protection for 8 weeks, then infestation appeared at 10th week, with 6.5 eggs/tuber till 12th week, with 6.6, while mint, coriander, zygophyllum, and harmel exhibited protection for 6 weeks, then infestation increased slowly until the 12th week, with a very low infestation, reached 1.8 to $7.3 \%$ at 8 th week increased to 4.11 to $9.66 \%$ at 12th week. Basil had less protection to the tubers than the previous extracts at 12 th week. Its protection was 9.04 compared to 30 at the control treatments. The other reaming extracts could arranged ascendingly in their protection up to the 12th week as follows: colocynth 15.74 < jasmine 19.7 < geranium 22.44 < senna $24.03<$ chamomile 25.53 compared with the 2 control talcum powder 29.4 and untreated tubers about 30 mean number of infestation/tuber. Damage evidence of the potato tubers treated with the plant extracts showed 6 extracts that completely protected the tuber from infestation were mint, coriander, zygophyllum, arnoglosse, harmel, and solanum, followed by basil < colocynth $<$ jasmine nearly $=$ geranium $<$ senna $=$ chamomile, compared to the high infestation of both 2 control experiments, talcum powder and untreated control tubers (Fig. 2). The effect of the tested plant extracts was related to their phytochemical constituents and secondary metabolites of active ingredients extracted by $80 \%$ ethanol alcohol (riat and ohri, 2018). The present results agree with some other investigations. The presence of the basil extract played a role as repellent against the female moth, which possess olfactory and contact chemoreceptors that repelled by the odor of volatile chemicals of plants. Sharaby et al. (2002) speculated that plant odor acted as feeding and oviposition deterrents to a wide variety of insect pests. Recently, numerous studies indicated that many wild medicinal and ornamental plants have pesticidal properties, which show antifeedant, repellent, growth regulator effects, and toxic activities on a wide range of insect pests (Khan and Gumbs, 2003; Sharaby et al. 2009; Stevenson, 2014, and Onu et al. 2015). Sisay and Ibrahim (2012) concluded that $L$. camara, E. globulus, and Pyrethrum flowers can be used to protect seed potatoes from damage. Sharaby et al. (2012) reported Allium cepa, Pelargonium graveolens, and Cymbopogon citrates oils caused great reduction in larval infestation of treated tubers. Mahmoud et al. (2017) recorded an effect of basil leaves powder and their ethanolic extract against the 3rd larval instar of
Anopheles arabiensis. Plant odor acts as feeding and oviposition deterrents to a wide variety of insect pests. It was also effective as fumigant (Koul et al. 2008). Ethanolic extract of the tested mentioned plants induced promising effect as a protector for the potato tubers against the PTM infestation during storage period and marketing, and reduced the need for the use of chemical insecticides and its associated risks. Obtained results suggested an interesting opportunity to develop biological pesticides based on plant extracts for the control of serious lepidopteran pests during storage that may affect production and the national economy.

\section{Conclusion}

Some plant extracts induced a complete protection of treated tubers from PTM infestation during storage. Great effects were found in development and metamorphosis of the larvae. Obtained results suggested developing new available bio-insecticides based on plant extracts that succeeded to control PTM and protect the tubers for 3-12 weeks during storage and marketing without any effect on their germination.

\section{Acknowledgements \\ The authors are very grateful to all colleges for their valuable assist.}

\section{Authors' declaration}

All authors declare that the manuscript has not been sent for consideration for publication or for publication anywhere else before; the manuscript is original research data.

\section{Authors' contributions}

ASH suggested the research idea, designed the experiments, wrote the manuscript, reviewed the data, and edited and approved the manuscript. MAG wrote the manuscript, reviewed the data, managed tables and figures, and edited and approved the manuscript. SBF made the experiments, recorded and analyzed the data, prepared the tables, assisted in writing the manuscript, and approved the manuscript.

\section{Funding}

The experimental work is not financially funded by any agent.

Availability of data and materials

All data on which abstract of the study have been drawn are presented in the main manuscript

Ethics approval and consent to participate

Not applicable

Consent for publication

Not applicable

\section{Competing interests}

The authors declare that they have no competing interests.

\section{Author details}

${ }^{1}$ Pests \& Plant Protection Dept. Agricultural \& Biological Researches Division, National Research Centre, Cairo, Egypt. Biology Department, College of Science, Imam Abdel Rahman Bin Faisal University, Dammam, Kingdom of Saudi Arabia. 
Received: 22 April 2020 Accepted: 30 June 2020

Published online: 10 July 2020

\section{References}

Abbott WS (1925) A method of computing the effectiveness of insecticide. J Ecol Entomol 18:265-267

Chandel BS, Dubey I, Tewari A (2018) Screening of plant extract for insecticidal biopotancy against Callosobrucus chinensis L. (Coleoptera: Bruchidae) on chickpea, Cicer aritenum L. Int J Entomol Res 3(1):101-106

El-Sherif ARA (1966) Studies on the morphology and biology of the potato tuber moth Phthorimaea operculella (Zeller.) M.Sc. Thesis. Agric. Cairo. Univ. 97p.

Fenemore PG (1980) Oviposition of potato tuber moth Phthorimaea operculella (Zell.) (Lepidoptera: Gelechiidae) identification of host plant factors influencing oviposition response. N Z J Zool 7:435-439

Freedman B, Nowak J, Kwolek WF, Berry EC, Guthrie WD (1979) Bioassay for plant derived pest control agent using the European corn borer. J Econ Ent 72: $541-545$

Isman MB (2008) Botanical insecticides: for rich, for poorer. Pest Management Sci 64:8-11

Khan MA, Gumbs FA (2003) Repellent effect of Ackee (Blighia sapida Koenig) component fruit parts against stored product insect pests. J Trop Agric 80: 19-27

Koul O, Walia S, Dhaliwal GS (2008) Essential oils as green pesticides: potential and constrains. Biopestic Int 4(1):63-84

Mahmoud HEMA, Bashir NHH, Assad YOH (2017) Effect of basil (Ocimun basilicum) leaves powder and ethanolic-extract on the $3^{\text {rd }}$ larval instar of Anopheles arabiensis (Patton, 1905)(Culicidae: Diptera). Int J Mosquito Res 4(2):52-56

Mathew LK (2016) Botanicals as Biopesticides: A review. Int J Adv Res 4(3):17341739

Onu FM, Ogu E, Ikehi ME (2015) Use of Neem and Garlic dried plant powders for controlling some stored grains pests. Egypt J Biol Pest Control 25(2):507-512

Riat AK, Ohri S (2018) Effect of phytochemicals against different pests: a review. Int J Adv Res 6(6):999-1003

Rondon SI (2010) The Potato tuber worm: a literature review of its biology, ecology and control. Am J Potato Res 87:149-166

Sharaby A (1988) Effect of orange, Citrus sinensis (L.) peel oil on reproduction in Phthorimaea operculella (Zeller.). Insect Sci Its Appl 9:201-203

Sharaby A, Abdel Rahman HA, Moawad S (2002) Sensors of the Potato tuber moth Phthorimaea operculella (Zeller) (Lepidoptera: Gelechiidae). Bull NRC Egypt 27(1):131-147

Sharaby A, Abdel-Rahman H, Moawad S (2009) Biological effects of some natural and chemical compounds on the potato tuber moth, Phthorimaea operculella Zell. (Lepidoptera: Gelechiidae). Saudi J Biol Sci 16:1-9

Sharaby A, Sayed AM, Youssef AM, Sobhi Al (2012) Natural Plant Essential Oils for Controlling the Grasshopper (Heteracris littoralis) and their Pathological Effects on the Alimentary Canal. Ecologia Balkanica 4(1):39-52

Sisay A, Ibrahim A (2012) Evaluation of some potential botanicals to control potato tuber moth, (Phthorimaea operculella) under storage condition at Bako. Western Ethiopia, International Journal of Phytopathology, ISSN: 2312 $1(1): 14-18$

Stevenson PC (2014) Using pesticidal plants for crop protection. Royal Botanic Gardens. http://www.kew.org/discover/blogs/using-pesticidal-plants-cropprotection (accessed 22 March, 2015).

\section{Publisher's Note}

Springer Nature remains neutral with regard to jurisdictional claims in published maps and institutional affiliations.

\section{Submit your manuscript to a SpringerOpen ${ }^{\circ}$ journal and benefit from:}

- Convenient online submission

- Rigorous peer review

- Open access: articles freely available online

- High visibility within the field

- Retaining the copyright to your article

Submit your next manuscript at $\boldsymbol{\nabla}$ springeropen.com 